\title{
Current Status of Patient-Derived Ovarian Cancer Models
}

\author{
Yoshiaki Maru and Yoshitaka Hippo *(D) \\ Department of Molecular Carcinogenesis, Chiba Cancer Center Research Institute, Chiba 260-8717, Japan; \\ ymaru@chiba-cc.jp \\ * Correspondence: yhippo@chiba-cc.jp; Tel.: +81-43-264-5431
}

Received: 30 April 2019; Accepted: 23 May 2019; Published: 25 May 2019

\begin{abstract}
Ovarian cancer (OC) is one of the leading causes of female cancer death. Recent studies have documented its extensive variations as a disease entity, in terms of cell or tissue of origin, pre-cancerous lesions, common mutations, and therapeutic responses, leading to the notion that OC is a generic term referring to a whole range of different cancer subtypes. Despite such heterogeneity, OC treatment is stereotypic; aggressive surgery followed by conventional chemotherapy could result in chemo-resistant diseases. Whereas molecular-targeted therapies will become shortly available for a subset of $O C$, there still remain many patients without effective drugs, requiring development of groundbreaking therapeutic agents. In preclinical studies for drug discovery, cancer cell lines used to be the gold standard, but now this has declined due to frequent failure in predicting therapeutic responses in patients. In this regard, patient-derived cells and tumors are gaining more attention in precise and physiological modeling of in situ tumors, which could also pave the way to implementation of precision medicine. In this article, we comprehensively overviewed the current status of various platforms for patient-derived OC models. We highly appreciate the potentials of organoid culture in achieving high success rate and retaining tumor heterogeneity.
\end{abstract}

Keywords: ovarian cancer; patient-derived cells; organoid; spheroid; xenograft; pre-clinical model; precision medicine; drug discovery

\section{Introduction}

Ovarian cancer (OC) is the most devastating gynecologic cancer. Even after development of many surgical techniques and chemotherapies, its overall five-year survival rate is still as low as $47 \%$ [1]. The prognosis appears favorable if patients are diagnosed at early stages, but early detection is generally difficult due to manifestation of non-specific symptoms and the lack of reliable biomarkers.

With many histological variations, $\mathrm{OC}$ has been regarded as a highly heterogeneous disease. Indeed, epithelial OC that comprises nearly $90 \%$ of OC is usually classified into many histologically distinct subtypes. Major subtypes include serous carcinoma, endometrioid carcinoma, clear cell carcinoma, and mucinous carcinoma. Recently, epithelial OC are more loosely classified into two general categories by integrating the results from histopathological, molecular biological, and genetic analyses, to underscore biological properties of OC. Type 1 cancers grow slowly and contain low-grade serous carcinoma (LGSC), mucinous carcinoma, endometrioid carcinoma, clear cell carcinoma, and transitional carcinoma. Type 2 cancers progress rapidly and contain high-grade serous carcinoma (HGSC), undifferentiated carcinoma, and carcinosarcioma [2]. This dualistic model of ovarian cancers was further revised and expanded to provide more detailed classification [3]. Researchers used to automatically assume that most epithelial OC would derive from ovarian surface epithelium (OSE), but accumulating evidence strongly suggests that its cell of origin might differ by histological subtypes. For example, it has been established that HGSC predominantly originates from secretory cells or 
progenitor cells in the fallopian tubes, via pre-malignant lesions known as serous tubal intraepithelial carcinoma (STIC) [4]. Endometrioid carcinoma and clear cell carcinoma are highly correlated with a history of endometriosis, in which endometrial cells implanted on the ovary are the likely origin of the tumors $[5,6]$. Genome analysis revealed that differences in mutation profiles underlie histological subtypes. Whereas TP53 is exclusively mutated in HGSC in a proportion as high as 95\% [7], RAS and $B R A F$ are frequently mutated in LGSC [8]. KRAS mutation is also implicated in mucinous carcinoma [9]. Clear cell carcinoma is characterized by ARID1A, PIK3CA, TERT promoter mutations [10-12], and endometrioid carcinoma is characterized by PTEN, PIK3CA, ARID1A, and CTNNB1 mutations [13]. However, some tumors are not consistent with these typical features, hence molecular mechanisms underlying carcinogenesis of each OC subtype are not fully understood.

Despite the highly heterogeneous nature of $\mathrm{OC}$, standard treatment of ovarian cancer is stereotypically composed of aggressive surgery followed by platinum-taxane chemotherapy. Of the four major subtypes, clear cell carcinoma and mucinous carcinoma tends to be refractory to chemotherapy $[14,15]$. Moreover, recurrence after initial chemotherapy often results in platinum-resistant diseases, leading to low overall five-year survival rates. To overcome this issue, some new therapeutic agents are in trial for OC. Representative examples include PARP inhibitors for cases deficient in homologous recombination repair, often caused by inactivation of $B R A C A 1$ or $B R C A 2$ [16], and molecular targeted agents against vascular endothelial growth factor (VEGF) [17]. Nonetheless, treatment options of ovarian cancer are still limited, requiring new therapeutic options. For efficient drug discovery, preclinical models that accurately mimic biological properties of in vivo human tumors would be of great value. In this regard, patient-derived materials are currently becoming indispensable and will also be useful in precision medicine. Along with recent implementation of precision medicine, high-throughput genome sequencing analysis has been applied to explore effective therapeutic strategies for each patient [18]. However, identification of druggable targets may not necessarily warrant efficacy of the drug in a clinical setting. Assays with patient-derived cells, by direct administration of drugs to cells in vitro or to xenografts, would therefore be helpful in predicting drug response.

Such patient-derived models, especially primary cell culture, have not been intensively developed for OC thus far, unlike for cancers of other vital organs. It is not clear whether this is because of any technical difficulties specific to OC or researchers simply did not attempt to obtain patient-derived material for OC. In this article, we comprehensively overview the current status of various patient-derived platforms (Figure 1) and illustrate pros and cons of each system in OC to gain perspectives on potential issues to be circumvented in OC research. 


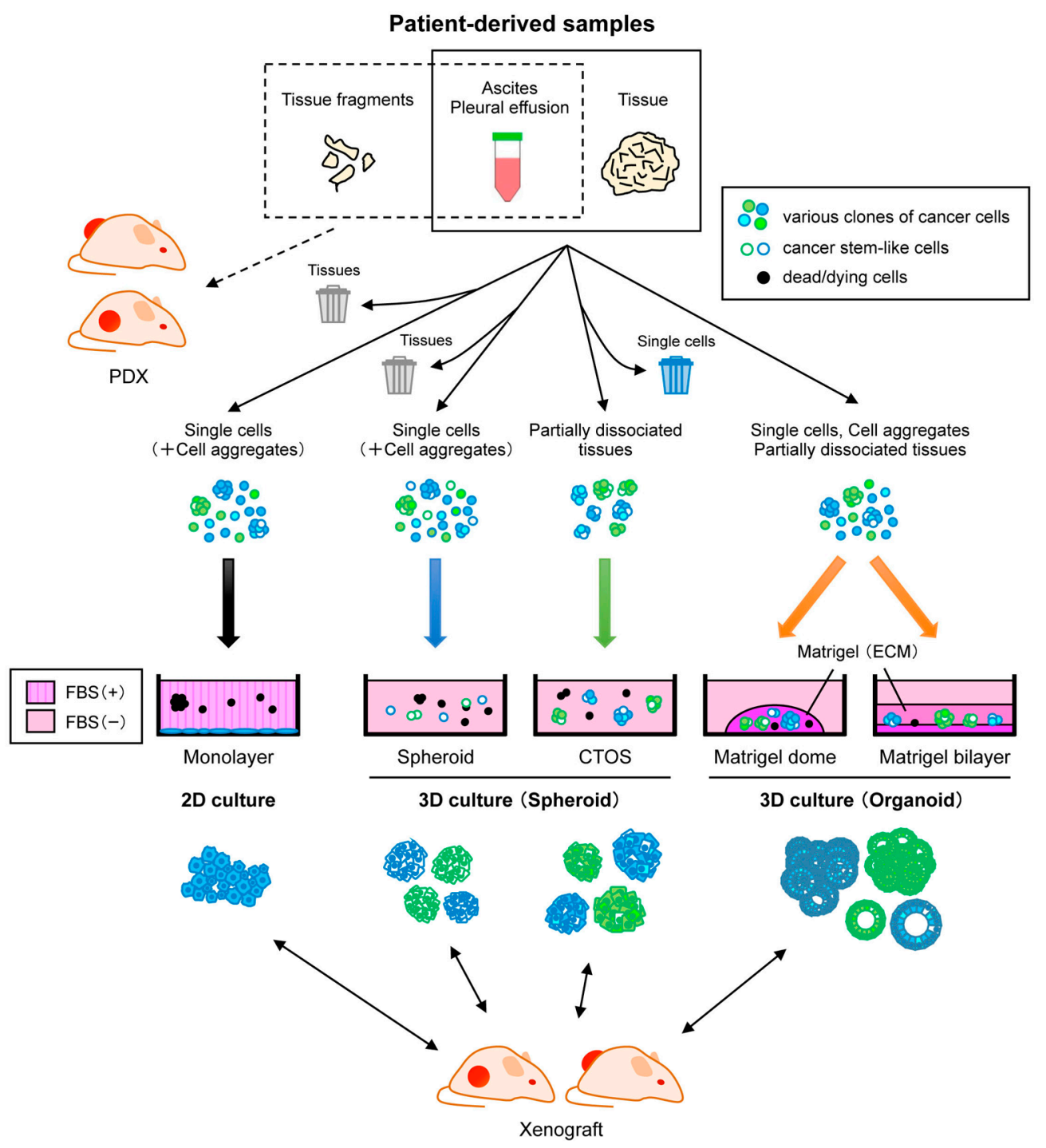

Figure 1. Representative approaches for establishing patient-derived cancer models from diverse clinical samples. Patient-derived xenografts (PDXs) are generated by direct engraftment of clinical samples into immunodeficient mice. Monolayer culture is a common culture method, but cells from primary tumors often undergo crisis, leading to positive selection of specific clones. Spheroid culture with serum-free media is suitable for enrichment of cancer stem-like cells. Cancer tissue-originated spheroids (CTOS) method initiates culture by maintaining cell-cell contact of cancer cells. In the presence of extracellular matrix (ECM) such as Matrigel, organoid culture can propagate both normal and cancer cells while retaining heterogeneity and differentiation. CTOS of ovarian cancer have been not documented yet. These cells cultured by various methods can be used to generate xenografts.

\section{Cancer Cell Lines}

\subsection{General Overview}

Cancer cell lines are special types of cells that acquire infinite proliferation potential on plastic dishes. They can expand as a monolayer sheet, with simple media that typically contains fetal bovine serum (FBS). For their high usability as adherent cells, cancer cell lines have long contributed to many areas of scientific research, including cell biology, biochemistry, physiology, and drug discovery, let alone cancer research [19]. To better interpret the results of experiments with cell lines, the Cancer Cell Line Encyclopedia (CCLE) has been released [20]. This catalog accommodates various molecular profiling, 
including genome and transcriptome, for around 1000 widely used cell lines derived from various cancer types. This resource will be helpful in linking experimental observations and clinical significance.

On the other hand, there are several drawbacks in cell lines. Firstly, they tend to be passaged too many times. As the success rate for establishing cell lines from primary tumor tissues is generally low, only a subset of cell lines has been extensively used, thereby cultured over a significantly long period of time or many passages. With the high potential of FBS-based cultures to introduce mutations and genome instability, cell lines could undergo drastic changes in terms of morphology and biological properties, presumably by selection of some specific clones. Consequently, even cell lines under the same name could harbor significant diversity between laboratories [21]. Diversity could arise even within the same laboratory between early and late passage. For example, as xenografts in immunodeficient mice, adenocarcinoma-derived cell lines may no longer exhibit a glandular structure and even exhibit undifferentiated histology. Secondly, there is a cross contamination issue in commonly used cell lines. As is so often observed, even cell lines from a large public-sector cell bank could suffer from this issue. Consequently, requirements for authentication of cell lines have become increasingly strict [22]. Presumably due to these two reasons, the responses of some cell lines to therapeutic agents, either in monolayer culture or as xenograft, were not recapitulated in many clinical trials [23,24], discouraging the use of cell lines as a pre-clinical model.

\subsection{Ovarian Cancer Cell Lines}

More than $50 \mathrm{OC}$ cell lines have been so far established and are currently available for research. As predicted, discrepancies in histology or mutation profiles between cell lines and original tumors were documented in a study that investigated in detail the validity of 47 OC cell lines derived from various OC subtypes [25]. Among the Pubmed literature that used any of these cell lines, the studies using SK-OV-3, A2780, OVCAR-3, CAOV3, or IGROV1 as HGSC models held a share of $90 \%$. However, genomic profiling of SK-OV-3 and A2780 analysis demonstrated TP53 was intact, although this is a hallmark mutation in HGSC. On the other hand, it detected mutations in ARID1A, BRAF, PIK3CA, and PTEN, which are commonly mutated in other subtypes of OC. Besides, OVCAR-3 and CAOV3 were not among the top-ranking HGSC cell lines based on integrative molecular profiling, although they in fact possessed TP53 mutations and substantial copy number change. IGROV1 had a hypermutated phenotype, which is frequently observed in endometrioid carcinoma rather than in HGSC. Strikingly, the 12 cell lines evaluated as best candidates for HGSC models accounted for only $1 \%$ of the Pubmed literature on the 47 analyzed cell lines. Morphological characterization of 39 OC cell lines also led to a similar conclusion that questioned SK-OV-3, S2780, and IGROV1 as representative models for HGSC [26]. These results strongly suggest that the most widely used "HGSC" cell lines might not in fact represent HGSC. In some non-serous OC cell lines, considerable discrepancies in gene mutations from earlier studies were observed as well [25], suggesting that the diversitification of the cell lines is another critical issue in OC research.

Tumorigenicity assay was conducted by inoculating 17 OC cell lines into the subcutis, peritoneal cavity, and ovaries of nude mice, revealing that the tumorigenicity varied among inoculation sites and cell lines [27]. For example, whereas OVCAR-3 did not proliferate in the subcutis, but formed tumors in the peritoneal cavity, HeyA8 formed tumors in either location. The integrated proteomic analysis has divided 26 OC cell lines into three categories: epithelial type, clear cell type, and mesenchymal type, and identified a protein signature that could potentially uncover the cell of origin for each OC subtype and corresponding driver proteins [28]. Collectively, it is therefore advisable to select OC cell lines appropriate for the purpose of the study by carefully examining the characteristics of the cell lines. 


\section{Patient-Derived Xenografts (PDXs)}

\subsection{General Overview}

Patient-derived xenografts (PDXs) are usually generated by directly engrafting tumor fragments into immunodeficient mice. Not only surgically resected tumors, but also samples from biopsy, ascites, and pleural effusion can be used. Inoculation sites are most commonly subcutaneous tissues. Depending on the tumor types and purposes of the experiments, orthotopic engraftment or intraperitoneal injection could be an option. Established PDXs can be serially engrafted to multiple mice without a culture step in between. Starting from primary tumors, the tumor take rate of PDX is generally higher than the success rate of establishing cancer cell lines. One possible explanation is that microenvironments reconstituted by interactions between subcutaneous tissues and tumor fragments might be physiological, accelerating tumor development faster than in cell lines, with only epithelial cells in an artificial condition. PDXs have been established from various types of cancer [29]. In most cases, histological features of the original tumors were basically retained, in terms of tissue structure and microscopic findings, including gland structures, mucin production, and cystic development. Moreover, PDXs also retained genetic aberrations and gene expression profiles of the original tumors [30], even after serial in vivo passages [31]. Importantly, reflecting these features, high correlation between therapeutic efficacy in PDX model and patients was documented [32]. These findings established PDXs as an indispensable preclinical model in drug discovery. However, the take rate significantly differs among cancer types and it is still challenging to efficiently develop PDXs from certain cancers, including breast [33] and prostate cancer [34]. Accordingly, optimization of the protocol for each tumor type seems necessary.

On the other hand, there are downsides to PDXs. Firstly, maintaining tumors in immunocompromised mice might be costly and require a more specialized skill in serial passage in mice, compared to simple monolayer cultures of cell lines. Besides, mice with more severely compromised immunity than nude mice might be eventually required to increase the tumor take rate. These mice include non-obese diabetic/severe combined immunodeficiency (NOD/SCID) mice, and NOD/SCID/IL2R $\gamma^{\text {null }}$ (NSG) mice, which could further involve a significant cost. For that reason, use of PDXs for high-throughput drug screening might be limited. Secondly, PDXs often require long latency to be established [35], and could therefore undergo tumor clonal evolution in a way to adapt to microenvironments in mice [36]. In principle, this effect may be inevitable to this experimental system, and needs to always be taken into account in interpretation of the results of any assays. But researchers have identified such mouse-specific signatures, potentially paving the way to subtract these artificial effects from the data. Thirdly, interactions between PDX and immune systems are totally different from those in humans. As mice lacking functional elements of immune systems are used for generation of PDX, critical differences lie in both species and immunity. To circumvent these issues, humanized mice have been developed. In these immune-deficient mice, CD34 ${ }^{+}$cells isolated from blood of the same patient were intravenously inoculated to reconstitute a functional human immune system [37]. PDXs with patient-matched immune systems may be valuable models for the evaluation of immune checkpoint inhibitors.

\subsection{PDX for Ovarian Cancer}

The first xenograft model for OC was described back in 1977, in which tumor tissue was engrafted into subcutaneous tissue of nude mice [38]. Several years later, PDXs were also established by intraperitoneal inoculation of tumor tissue or ascites-derived cancer cells [39], and orthotropic engraftment into the capsule of an ovary [40]. Since then, many studies have documented OC PDXs. As a large-scale study of OC PDXs, more than 150 OC PDXs have been established by intraperitoneal inoculation into SCID mice with a take rate of 74\% [41]. Implantation sites have been shown to affect the take rate of clinical OC samples [42], being relatively high in non-orthotropic sites such as subcutis and renal capsule, although these sites lack the microenvironment inherent to ovary or peritoneum [42,43]. Orthotropic OC models have several advantages over the models in other sites, 
because it can recapitulate tumor growth, metastasis, and ascites formation as observed in human disease [44-46]. OC cells in ascites were transduced ex vivo with luciferase and intraperitoneally inoculated to generate 14 OC PDX models [46], enabling non-invasive and simple evaluation of tumor burden. PDXs basically retained histological features and genome aberrations of the original OC. Genetic stability of OC xenografts was demonstrated even after serial transplantation into the renal capsule of NOD/SCID mice [47]. In mRNA profiling, HGSC PDXs successfully recapitulated three out of four human HGSC subtypes that were previously proposed by TCGA [7], with an exception for the immunoreactive subtype [48], which obviously requires the presence of intact immune system. As mRNA in the PDX could be derived from both murine and human cells, an efficient bioinformatics method was developed to extract only human transcripts from PDX transcriptome data obtained by RNA sequencing. It revealed that differentially expressed genes between the human tumors in PDX and the original tumors were mostly implicated in stromal components, suggesting the lack of human stroma might both directly and indirectly affect transcriptome of human components in the PDX [49].

The responses to platinum chemotherapy in OC PDXs were highly correlated with those in the donor patients [41,50-53], underscoring the validity of PDX as a preclinical model. Naturally, several potential candidates for therapeutics have been tested on PDXs established from platinum-resistant OC in an effort to overcome drug-resistance $[51,53,54]$. OC PDXs were also used to test the efficacy of targeted therapy [55]. For example, sensitivity to inhibitors targeting PARP, CHEK1, or ATR was investigated in BRCA-mutated OC PDXs to optimize therapeutic strategies for homologous recombination-deficient OC [56,57]. Hedgehog pathway, upregulated in a subset of OC [58], was also targeted with a specific inhibitor, leading to significant decrease of tumor volume in OC PDX [59]. More recently, combinatorial therapy including both chemotherapeutic agents and HER2 inhibitors was evaluated on OC PDX [60]. Furthermore, tumorigenicity as xenografts per se proved to be inversely correlated with progression-free survival [61]. Based on these findings, the potential relevance of PDX in OC is highly appreciated in terms of both drug discovery and precision medicine. One caveat with OC PDXs is that they predominantly originate from HGSCs, and take rate and latency for other histological subtypes is low and long, respectively $[41,53,62]$. These issues are to be addressed for the future improvement of this approach to OC in general.

\section{Patient-Derived Cells}

\subsection{Two-Dimensional Adherent Culture}

\subsubsection{General Overview}

As mentioned earlier, establishment of cell lines from primary cultures of patient-derived samples has only a low efficiency. For example, only 10 breast cancer cell lines were established out of 135 resected primary tumors [63]. Other researchers also established 18 breast cancer cell lines, but with a success rate of $10 \%$ [64]. This inefficiency might be partly due to the challenging adaptation of primary cancer cells to an adhesive monolayer culture. Cancer cells frequently lose growth potential after some passages and go into crisis, suggesting that overcoming replicative senescence might be a critical step in becoming a cell line under culture conditions with FBS. Even in successful cases, loss of tumor heterogeneity and proliferation of specific clones were commonly observed during in vitro adaptation. In a long-term serial passage of uveal melanoma (UM) cell lines, severe reduction of the expression of genes encoding UM markers MART-1, and p16 was observed [65].

\subsubsection{Ovarian Cancer Cell Lines}

Intriguingly, 25 novel cell lines were recently established from primary OC with significantly high efficiency, by using culture media and conditions optimized to each histological subtype [66]. More importantly, it was shown that these established cells retained the genomic landscape, histopathology, 
and molecular features of the original tumors. While how such a high success rate could be achieved needs to be clarified, if this method proves robust enough, it will benefit a broad area of cancer research.

\subsection{Three-Dimensional Culture}

\subsubsection{Spheroid Culture}

\section{General Overview}

Spheroids are sphere-like cell aggregates, which are usually maintained as floating three-dimensional structures. Among various spheroid culture methods so far documented [67], the standard protocol is as follows. Tumor tissues are subjected to physical and enzymatic dissociation, followed by filtration with cell strainers, or cell sorting by flow cytometry with stem cell markers. Subsequently, obtained single cell suspensions are cultured in low-attachment plates with serum-free media. Tumor-derived spheroids can develop from a single cell or cell aggregates. Culture supplements include growth factors, such as epidermal growth factor (EGF) and fibroblast growth factor (FGF). It is generally accepted that cell populations with stem cell-like properties will be functionally enriched by spheroid culture. As cancer stem cell theory argues that malignant phenotypes of cancer are mainly mediated by such stem cell-like fractions, spheroid cultures are most commonly adopted in investigations of drug resistance and metastasis [68-70]. Spheroids can be also used to generate PDXs, thereby evaluating the tumorigenicity of the original tumors. However, normal epithelial cells do not grow in spheroid culture conditions, therefore there is a lack of a reference sample on the same platform.

\section{Ovarian Cancer Spheroids}

For OC patients, drug resistance and peritoneal dissemination accompanied by cancerous ascites are two major factors that could profoundly affect prognosis. Given the morphological similarity between tumor cell aggregates within cancerous ascites and tumor spheroids in culture, it was natural that researchers initiated spheroid culture studies of $\mathrm{OC}$ with cancerous ascites samples. As was observed in other types of cancer, only a subset of ascites-derived cancer cells exhibited stem-cell like properties, which indeed developed tumors in immune-deficient mice [71]. Resected tumor samples from five ovarian HGSC were subjected to spheroid culture, and cell surface protein CD117 and CD44 were identified as tumor-initiating cell markers [72]. Detailed analysis of spheroids revealed a reciprocal regulatory circuit involving ALDH1 and SOX2 in OC stem cells [73]. Drug sensitivity for cisplatin, ALDH inhibitors, and the JAK1/2 inhibitor ruxolitinib was also evaluated using a hanging drop spheroid culture of $\mathrm{ALDH} 1^{+} \mathrm{CD} 133^{+}$stem cells derived from cancerous ascites of OC patients [74]. Throughout these studies, serous carcinomas of advanced stage, predominantly obtained from ascites, were exclusively used as sources of spheroids. Future refinement of protocols will therefore be necessary to extend the application of this approach to other types of OC.

\section{Non-Single Cell-Based Approaches}

For spheroid culture, standard preparation of tumor samples begins by obtaining singly dissociated cells. However, this was originally optimized for hematopoietic cells or neuronal cells, by which stem cell biology has considerably evolved. In sharp contrast, destruction of cell-cell adhesion could readily induce anoikis for epithelial cells, which significantly lowers the success rate of spheroid formation for many types of tumors of epithelial origin. To address this issue, only partially digested colorectal cancer (CRC) tissues were selectively subjected to spheroid formation, resulting in substantial improvement of the success rate of primary culture [75]. This approach, designated as the cancer tissue-originated spheroids (CTOS) method, has been successfully applied to various tumor tissues, including cancer of the colon [75], endometrial [76], and lung [77]. Established CTOS basically retained features of the original tumors and was feasible for in vitro high-throughput drug screening with CRC samples [78]. As CTOS do not grow beyond a certain volume, they are usually required to be physically fragmented, 
but not completely dissociated into single cells, for efficient passage. Alternatively, CTOS can be diverted to xenografts for extensive propagation of cancer cells, which can be in turn switched to CTOS again. While OC-derived CTOS has not been documented yet, given the simple and robust nature of the method, its application to patient-derived OC samples will be expected in the near future. With another culture technique, in which minced tumor tissues were used for spheroid culture for three to six months, 12 spheroid cell lines were established, and high-throughput assay for anti-cancer agents conducted [79].

\subsubsection{Organoid Culture}

\section{General Overview}

An organoid is an emerging concept that is literally a mini-organ exclusively composed of epithelial cells. Without the aid of a stromal niche, even a single normal stem cell can differentiate into all the lineages of the organ, while stem cells self-renew, thereby reconstituting in vivo homeostasis of the whole organ. In 2009, it was first demonstrated that murine intestinal stem cells marked by LGR5 ${ }^{+}$ could infinitely proliferate in vitro [80]. This study was based on the idea that stem cell niches would be alternatively reconstituted without stroma by defined factors and matrices. Intestinal stem cells are characterized by an activated Wnt pathway and inhibition of the bone morphogenetic protein (BMP) pathway. Besides, it was known that extracellular matrix laminin is enriched in the niche. Specifically, isolated intestinal crypts were embedded in Matrigel with abundant laminin, and cultured in a serum-free media supplemented with R-spondin 1, which is a WNT agonist and ligand of LGR5, epidermal growth factor (EGF), and the bone morphogenetic protein (BMP) inhibitor Noggin. Consequently, tissue homeostasis was reconstituted in vitro and the stem cells formed self-organizing organotypic structures referred to as organoids. Under the same concept, the original experimental protocol was further optimized for various murine and human normal organs [81-83]. Its application has been extended to many fields, including bacterial infection [84], developmental biology [85], and epithelial regeneration [86].

\section{Organoid-Based Carcinogenesis Model}

Organoids can be subjected to genetic engineering by viral introduction of shRNA and cDNA. With highly efficient lentiviral gene transduction into murine organoids [87], we demonstrated that the whole processes of multi-step carcinogenesis could be recapitulated for the intestine, lungs and the biliary tract, as subcutaneous tumors in nude mice [88-90]. Essentially similar results to earlier in vivo studies were obtained in a significantly shorter period of time, suggesting that this approach might at least partly substitute and complement the conventional gene-targeting approach in modeling carcinogenesis. Similarly, multiple genetic alterations were reconstituted in human colon organoids with CRISPR/Cas9 technology to generate full-blown tumors, although premalignant or benign lesions were not recapitulated in immunodeficient mice [91,92]. These organoid-based carcinogenesis models might be useful for elucidation of the molecular mechanisms underlying carcinogenesis.

\section{Primary Tumor Organoid}

Organoid culture techniques can be applied to various patient-derived samples, such as resected tissue, biopsy, ascites, and pleural effusions. Obvious advantages of organoid culture over PDX and spheroid culture include that it allows propagation of normal cells and precancerous cells, and a higher success rate for cancer cells. In CRC, the success rate of organoid culture was significantly higher than that of PDX or spheroid culture [93]. Given that cancer is not an organ in a strict sense, one might argue that it may not be adequate to use the term "organoids" for cancer cells. However, many researchers stretched the interpretation of the term by taking cancer stem cells as an analogy of tissue stem cells. Accordingly, patient-derived cells propagated in Matrigel were defined as tumor-derived organoids in this review. On the other hand, some researchers appear to go beyond that definition, by 
referring to patient-derived cells that were cultured by any 3D culture methods, spheroids for instance, as "organoids". Such confusion in nomenclature needs to be taken into account when looking into the literature.

Establishment of tumor-derived organoids from various cancer types has been reported, namely colon [94], pancreatic [95], gastric [96], prostate [97], breast [98], esophageal [99], bladder [100], and endometrial cancers [101]. Whereas the success rate of organoid culture varies by cancer types and tumor grade, it reaches 80 to $90 \%$ in colon cancer. Propagated tumor-derived organoids basically retain both histological and genetic features of original tumors and are feasible for in vitro drug sensitivity assay [102], which recapitulates clinical responses of matched patients [103]. Collectively, tumor-derived organoids will likely serve as a promising resource for evaluating clinical response of individual patients. In addition, tumor-derived organoids were used in high-throughput drug screening for precision medicine. For example, drug screening of a library containing more than 50 compounds was conducted with 19 colorectal cancer organoids, demonstrating correlation between drug sensitivity and genetic aberrations [104]. Thirty-seven anti-cancer drugs were screened in nine gastric cancer organoids, which identified a good response toward some new target drugs [96]. Also, various applications are under way, such as secondary establishment of xenografts and single cell analysis [105].

On the other hand, there are several shortcomings in organoid culture. Firstly, tumor-derived organoids lack stroma, immune cells, and blood vessels. To address this issue, some co-culture systems involving pancreatic ductal adenocarcinoma-derived organoids and murine pancreatic stellate cells was established to investigate interactions between cancer cells and cancer-associated fibroblasts [106]. Recently, tumor sensitivity to T cell-mediated immune response was also evaluated, by co-culturing colorectal cancer or non-small cell lung cancer-derived organoids and peripheral blood lymphocytes [107]. Secondly, organoid culture is costly in comparison with conventional 2D culture due to supplemental factors and extra cellular matrix such as Matrigel. However, conditioned medium derived from L-WRN cells, which secrete Wnt3a, R-spondin3, and Noggin, became available for organoid culture, at least partially circumventing this issue $[108,109]$. Thirdly, the success rate of organoid culture is not high enough in a subset of tumor types. Besides, establishment of organoids from tiny clinical samples is still technically challenging. However, tumor-derived organoids could be established from biopsy samples [110], suggesting improvements in success rate. Similarly, further improvement of organoid culture technique might ultimately enable establishment of organoids from circulating tumor cells and tumors spread in spinal fluid. Lastly, culture and assay protocols currently vary among researchers and laboratories, even for the same cancer types. Such differences might potentially affect the outcomes of drug screening assays.

\section{Ovarian Cancer Organoid}

Unlike many other types of cancer, only a few studies have documented organoid cultures of OC (Table 1). Drug response of OC cells in monolayer cultures and organoid cultures was compared by using cancer cells collected from tumor tissues, ascites and pleural effusions of metastatic serous OC. Drug effects in organoids proved more diverse and rather refractory [111]. Patient-derived HGSC organoids were developed with a high success rate and used for functional profiling of DNA repair, accurately predicting clinical response of patients to DNA repair inhibitors [112]. More recently, comprehensive establishment of 56 OC organoid lines from 32 OC cases was reported [113]. Although two-thirds of organoids were derived from serous OC in this study, it achieved a success rate of $65 \%$. Notably, it covered all the four major subtypes for the first time and basic features of the original tumors were mostly retained. Moreover, organoids established from normal fallopian tube and OSE were subjected to p53 inactivation to model HGSC. We also established an efficient organoid culture method for ovarian and endometrial tumors [114]. We modified a Matrigel bilayer organoid culture protocol (MBOC), originally developed for a murine carcinogenesis model ex vivo [115], to cope with the digestion-resistant nature of OC. A total of nine OC-organoid lines were established from not 
only HGSC, but also mucinous, endometrioid carcinoma, and even borderline or early-stage tumors. Propagated organoids retained many aspects of the original tumors, including histopathological features, mutation profiles, and intra-tumoral heterogeneity. Drug response assay was also feasible using organoid-derived spheroids. Thus, the organoid platform might be potentially promising in drug discovery and personalized medicine.

Table 1. List of studies on primary organoid culture of ovarian cancers.

\begin{tabular}{|c|c|c|c|c|c|}
\hline Reference & \multicolumn{2}{|c|}{ Success } & Histological Type & Patient's Material & PDX \\
\hline [102] & 1 & 100 & N.D. & N.D. & N.T. \\
\hline [112] & 23 & $80-90$ & HGSC, CS & Tissue, Pleural effusion & N.T. \\
\hline [113] & 32 & 65 & MBT, SBT, CCC, EMC, MC, LGSC, HGSC & Tissue, Ascites, Pleural effusion & Yes \\
\hline [114] & $9\left(4^{*}, 5^{\#}\right)$ & $60\left(44^{*}, 83^{\#}\right)$ & BBT, SBT, EMC, MC, HGSC & Tissue & Yes \\
\hline
\end{tabular}

SC, serous carcinoma; HGSC, high-grade SC; LGSC, low-grade SC: CS, carcinosarcoma, CCC, clear cell carcinoma, EMC; endometrioid carcinoma; MBT, mucinous borderline tumor, SBT, serous borderline tumor; BBT, borderline Brenner tumor; N.D., not described; N.T., not tested.; PDX, patient-derived xenograft; *standard Matrigel bilayer organoid culture (MBOC); \#modified MBOC.

To better understand the biological features of $\mathrm{OC}$, thorough elucidation of interactions between tumor cells and the microenvironment is a critical issue. However, standard organoid culture consists of only epithelial cells and lacks such interactions. To address this issue, 3D organotypic models that reproduce a similar situation to that in vivo have been developed [116]. Specifically, the microenvironment of OC was first reconstituted in vitro, by using omentum-derived primary mesothelial cells and fibroblast at early passages. OC cells were then plated to examine the mechanisms underlying attachment and invasion of OC. Another model is a 3D microfluid-based model that dynamically reconstitutes interactions of $\mathrm{OC}$ with mesothelial cells during peritoneal dissemination. In this platform, living cells are infused into micrometer-sized chambers, enabling accurate control of the cellular microenvironment [117]. While these organotypic co-culture models are complex systems and may not be ideal for robust propagation of organoids, their physiological features might be suitable for drug discovery in the next-generation.

\section{Conclusions}

Until very recently, use of patient-derived OC as preclinical models has been quite limited because the success rate of primary cultures was low, and even if cell lines are established, features often differ from those of the original tumors. Recent remarkable advances in 3D culture technique have allowed us to reconstitute many features of the original tumors in an in vitro setting. In the light of rapid implementation of precision medicine, which largely depends on genomic information of each cancer, establishment of patient-derived cell-based assays will be of critical relevance. Among various platforms, the organoid might be the most powerful tool in high-throughput drug screening and establishment of xenografts. Now that OC organoids are becoming available, its nation-wide banking will be readily started as a valuable resource for OC researches. Collectively, OC organoids per se and organoid-derived PDX will likely contribute to the development of novel therapies as well as elucidation of its pathogenesis.

Funding: This work was supported in part by research grants from Chiba Prefecture and KAKENHI (19K09816) from the Japan Society for the Promotion of Science.

Acknowledgments: We thank all the members of the Hippo lab and the collaborators in Chiba Cancer Center for helpful discussion and kind support. This work was supported in part by research grants from Chiba Prefecture and KAKENHI (19K09816) from the Japan Society for the Promotion of Science.

Conflicts of Interest: The authors have no conflict of interests. 


\section{References}

1. Siegel, R.L.; Miller, K.D.; Jemal, A. Cancer statistics, 2019. CA Cancer J. Clin. 2019, 69, 7-34. [CrossRef] [PubMed]

2. Koshiyama, M.; Matsumura, N.; Konishi, I. Recent Concepts of Ovarian Carcinogenesis: Type I and Type II. Biomed Res. Int. 2014, 2014, 1-11. [CrossRef]

3. Kurman, R.J.; Shih, I.-M. The Dualistic Model of Ovarian Carcinogenesis: Revisited, Revised, and Expanded. Am. J. Pathol. 2016, 186, 733-747. [CrossRef] [PubMed]

4. Labidi-Galy, S.I.; Papp, E.; Hallberg, D.; Niknafs, N.; Adleff, V.; Noé, M.; Bhattacharya, R.; Novak, M.; Jones, S.; Phallen, J.; et al. High grade serous ovarian carcinomas originate in the fallopian tube. Nat. Commun. 2017, 8, 1093. [CrossRef]

5. Ayhan, A.; Mao, T.-L.; Seckin, T.; Wu, C.-H.; Guan, B.; Ogawa, H.; Futagami, M.; Mizukami, H.; Yokoyama, Y.; Kurman, R.J.; et al. Loss of ARID1A expression is an early molecular event in tumor progression from ovarian endometriotic cyst to clear cell and endometrioid carcinoma. Int. J. Gynecol. Cancer. 2012, 22, 1310-1315. [CrossRef]

6. Sato, N.; Tsunoda, H.; Nishida, M.; Morishita, Y.; Takimoto, Y.; Kubo, T.; Noguchi, M. Loss of heterozygosity on 10q23.3 and mutation of the tumor suppressor gene PTEN in benign endometrial cyst of the ovary: Possible sequence progression from benign endometrial cyst to endometrioid carcinoma and clear cell carcinoma of the ovary. Cancer Res 2000, 60, 7052-7056.

7. Integrated genomic analyses of ovarian carcinoma. Nature 2011, 474, 609-615. [CrossRef] [PubMed]

8. Hunter, S.M.; Anglesio, M.S.; Ryland, G.L.; Sharma, R.; Chiew, Y.-E.; Rowley, S.M.; Doyle, M.A.; Li, J.; Gilks, C.B.; Moss, P.; et al. Molecular profiling of low grade serous ovarian tumours identifies novel candidate driver genes. Oncotarget 2015, 6, 37663-37677. [CrossRef]

9. MacKenzie, R.; Kommoss, S.; Winterhoff, B.J.; Kipp, B.R.; García, J.J.; Voss, J.; Halling, K.; Karnezis, A.; Senz, J.; Yang, W.; et al. Targeted deep sequencing of mucinous ovarian tumors reveals multiple overlapping RAS-pathway activating mutations in borderline and cancerous neoplasms. BMC Cancer. 2015, 15, 200. [CrossRef] [PubMed]

10. Jones, S.; Wang, T.-L.; Shih, I.-M.; Mao, T.-L.; Nakayama, K.; Roden, R.; Glas, R.; Slamon, D.; Diaz, L.A.; Vogelstein, B.; et al. Frequent Mutations of Chromatin Remodeling Gene ARID1A in Ovarian Clear Cell Carcinoma. Science 2010, 330, 228-231. [CrossRef] [PubMed]

11. Wu, R.-C.; Ayhan, A.; Maeda, D.; Kim, K.-R.; Clarke, B.A.; Shaw, P.; Chui, M.H.; Rosen, B.; Shih, I.-M.; Wang, T.-L. Frequent somatic mutations of the telomerase reverse transcriptase promoter in ovarian clear cell carcinoma but not in other major types of gynecologic malignancy. J. Pathol. 2014, 232, 473-481. [CrossRef] [PubMed]

12. Maru, Y.; Tanaka, N.; Ohira, M.; Itami, M.; Hippo, Y.; Nagase, H. Identification of novel mutations in Japanese ovarian clear cell carcinoma patients using optimized targeted NGS for clinical diagnosis. Gynecol. Oncol. 2017, 144, 377-383. [CrossRef]

13. McConechy, M.K.; Ding, J.; Senz, J.; Yang, W.; Melnyk, N.; Tone, A.A.; Prentice, L.M.; Wiegand, K.C.; McAlpine, J.N.; Shah, S.P.; et al. Ovarian and endometrial endometrioid carcinomas have distinct CTNNB1 and PTEN mutation profiles. Modern Pathol. 2014, 27, 128. [CrossRef]

14. Pectasides, D.; Fountzilas, G.; Aravantinos, G.; Kalofonos, C.; Efstathiou, H.; Farmakis, D.; Skarlos, D.; Pavlidis, N.; Economopoulos, T.; Dimopoulos, M.A. Advanced stage clear-cell epithelial ovarian cancer: The Hellenic cooperative oncology group experience. Gynecol. Oncol. 2006, 102, 285-291. [CrossRef]

15. Hess, V.; A’Hern, R.; Nasiri, N.; King, D.M.; Blake, P.R.; Barton, D.P.; Shepherd, J.H.; Ind, T.; Bridges, J.; Harrington, K.; et al. Mucinous Epithelial Ovarian Cancer: A Separate Entity Requiring Specific Treatment. J. Clin. Oncol. 2004, 22, 1040-1044. [CrossRef] [PubMed]

16. Lord, C.J.; Ashworth, A. PARP inhibitors: Synthetic lethality in the clinic. Science 2017, 355, $1152-1158$. [CrossRef]

17. Monk, B.J.; Minion, L.E.; Coleman, R.L. Anti-angiogenic agents in ovarian cancer: Past, present, and future. Ann. Oncol. 2016, 27, i33-i39. [CrossRef] [PubMed]

18. Zehir, A.; Benayed, R.; Shah, R.H.; Syed, A.; Middha, S.; Kim, H.R.; Srinivasan, P.; Gao, J.; Chakravarty, D.; Devlin, S.M.; et al. Mutational landscape of metastatic cancer revealed from prospective clinical sequencing of 10,000 patients. Nat. Med. 2017, 23, 703-713. [CrossRef] 
19. Greshock, J.; Bachman, K.E.; Degenhardt, Y.Y.; Jing, J.; Wen, Y.H.; Eastman, S.; McNeil, E.; Moy, C.; Wegrzyn, R.; Auger, K.; et al. Molecular Target Class Is Predictive of In vitro Response Profile. Cancer Res 2010, 70, 3677-3686. [CrossRef]

20. Barretina, J.; Caponigro, G.; Stransky, N.; Venkatesan, K.; Margolin, A.A.; Kim, S.; Wilson, C.J.; Lehár, J.; Kryukov, G.V.; Sonkin, D.; et al. The Cancer Cell Line Encyclopedia enables predictive modeling of anticancer drug sensitivity. Nature 2012, 483, 603-607. [CrossRef]

21. Ben-David, U.; Siranosian, B.; Ha, G.; Tang, H.; Oren, Y.; Hinohara, K.; Strathdee, C.A.; Dempster, J.; Lyons, N.J.; Burns, R.; et al. Genetic and transcriptional evolution alters cancer cell line drug response. Nature 2018, 560, 325-330. [CrossRef]

22. Masters, J.R.W. Human cancer cell lines: Fact and fantasy. Nat. Rev. Mol. Cell Biol. 2000, 1, $233-236$. [CrossRef] [PubMed]

23. Arrowsmith, J. Trial watch: Phase III and submission failures: 2007-2010. Nat. Rev. Drug Discov. 2011, 10, 87. [CrossRef]

24. Arrowsmith, J.; Miller, P. Trial watch: Phase II and phase III attrition rates 2011-2012. Nat. Rev. Drug Discov. 2013, 12, 569. [CrossRef]

25. Domcke, S.; Sinha, R.; Levine, D.A.; Sander, C.; Schultz, N. Evaluating cell lines as tumour models by comparison of genomic profiles. Nat. Commun. 2013, 4, 2126. [CrossRef] [PubMed]

26. Beaufort, C.M.; Helmijr, J.C.A.; Piskorz, A.M.; Hoogstraat, M.; Ruigrok-Ritstier, K.; Besselink, N.; Murtaza, M.; Van Ijcken, W.F.J.; Heine, A.A.J.; Smid, M.; et al. Ovarian Cancer Cell Line Panel (OCCP): Clinical Importance of In Vitro Morphological Subtypes. PLoS ONE 2014, 9, e103988. [CrossRef] [PubMed]

27. Hernandez, L.; Kim, M.K.; Lyle, L.T.; Bunch, K.P.; House, C.D.; Ning, F.; Noonan, A.M.; Annunziata, C.M. Characterization of ovarian cancer cell lines as in vivo models for preclinical studies. Gynecol. Oncol. 2016, 142, 332-340. [CrossRef]

28. Coscia, F.; Watters, K.M.; Curtis, M.; Eckert, M.A.; Chiang, C.Y.; Tyanova, S.; Montag, A.; Lastra, R.R.; Lengyel, E.; Mann, M. Integrative proteomic profiling of ovarian cancer cell lines reveals precursor cell associated proteins and functional status. Nat. Commun. 2016, 7, 12645. [CrossRef]

29. Gao, H.; Korn, J.M.; Ferretti, S.; Monahan, J.E.; Wang, Y.; Singh, M.; Zhang, C.; Schnell, C.; Yang, G.; Zhang, Y.; et al. High-throughput screening using patient-derived tumor xenografts to predict clinical trial drug response. Nat. Med. 2015, 21, 1318-1325. [CrossRef]

30. Cho, Y.B.; Hong, H.K.; Choi, Y.-L.; Oh, E.; Joo, K.M.; Jin, J.; Nam, D.-H.; Ko, Y.-H.; Lee, W.Y. Colorectal cancer patient-derived xenografted tumors maintain characteristic features of the original tumors. J. Surg. Res. 2014, 187, 502-509. [CrossRef]

31. Guenot, D.; Guerin, E.; Pencreach, E.; Schneider, A.; Neuville, A.; Chenard, M.-P.; Duluc, I.; Du Manoir, S.; Brigand, C.; Oudet, P.; et al. Primary tumour genetic alterations and intra-tumoral heterogeneity are maintained in xenografts of human colon cancers showing chromosome instability. J. Pathol. 2006, 208, 643-652. [CrossRef]

32. Byrne, A.T.; Alférez, D.G.; Amant, F.; Annibali, D.; Arribas, J.; Biankin, A.V.; Bruna, A.; Budinská, E.; Caldas, C.; Chang, D.K.; et al. Interrogating open issues in cancer precision medicine with patient-derived xenografts. Nat. Rev. Cancer. 2017, 17, 254-268. [CrossRef] [PubMed]

33. Zhang, X.; Claerhout, S.; Prat, A.; Dobrolecki, L.E.; Petrovic, I.; Lai, Q.; Landis, M.D.; Wiechmann, L.; Schiff, R.; Giuliano, M.; et al. A Renewable Tissue Resource of Phenotypically Stable, Biologically and Ethnically Diverse, Patient-Derived Human Breast Cancer Xenograft Models. Cancer Res. 2013, 73, 4885-4897. [CrossRef]

34. Nguyen, H.M.; Vessella, R.L.; Morrissey, C.; Brown, L.G.; Coleman, I.M.; Higano, C.S.; Mostaghel, E.A.; Zhang, X.; True, L.D.; Roudier, M.; et al. LuCaP Prostate Cancer Patient-Derived Xenografts Reflect the Molecular Heterogeneity of Advanced Disease and Serve as Models for Evaluating Cancer Therapeutics. Prostate 2017, 77, 654-671. [CrossRef] [PubMed]

35. Xu, C.; Li, X.; Liu, P.; Li, M.; Luo, F. Patient-derived xenograft mouse models: A high fidelity tool for individualized medicine. Oncol. Lett. 2019, 17, 3-10. [CrossRef]

36. Ben-David, U.; Ha, G.; Tseng, Y.-Y.; Greenwald, N.F.; Oh, C.; Shih, J.; McFarland, J.M.; Wong, B.; Boehm, J.S.; Beroukhim, R.; et al. Patient-derived xenografts undergo murine-specific tumor evolution. Nat. Genet. 2017, 49, 1567-1575. [CrossRef] 
37. Morton, J.J.; Bird, G.; Keysar, S.B.; Astling, D.P.; Lyons, T.R.; Anderson, R.T.; Glogowska, M.J.; Estes, P.; Eagles, J.R.; Le, P.N.; et al. XactMice: Humanizing mouse bone marrow enables microenvironment reconstitution in a patient-derived xenograft model of head and neck cancer. Oncogene 2016, 35, 290-300. [CrossRef] [PubMed]

38. Davy, M.; Mossige, J.; Johannessen, J.V. Heterologous Growth of Human Ovarian Cancer: A New in Vivo Testing System. Acta Obstet. Gynecol. Scand. 1977, 56, 55-59. [CrossRef]

39. Ward, B.G.; Wallace, K.; Shepherd, J.H.; Balkwill, F.R. Intraperitoneal xenografts of human epithelial ovarian cancer in nude mice. Cancer Res. 1987, 47, 2662-2667.

40. Fu, X.; Hoffman, R.M. Human ovarian carcinoma metastatic models constructed in nude mice by orthotopic transplantation of histologically-intact patient specimens. Anticancer Res. 1993, 13, 283-286.

41. Weroha, S.J.; Becker, M.A.; Enderica-Gonzalez, S.; Harrington, S.C.; Oberg, A.L.; Maurer, M.J.; Perkins, S.E.; Al Hilli, M.; Butler, K.A.; McKinstry, S.; et al. Tumorgrafts as in vivo surrogates for women with ovarian cancer. Clin. Cancer Res. 2014, 20, 1288-1297. [CrossRef] [PubMed]

42. Stewart, J.M.; Shaw, P.A.; Gedye, C.; Bernardini, M.Q.; Neel, B.G.; Ailles, L.E. Phenotypic heterogeneity and instability of human ovarian tumor-initiating cells. PNAS 2011, 108, 6468-6473. [CrossRef]

43. Dobbin, Z.C.; Katre, A.A.; Steg, A.D.; Erickson, B.K.; Shah, M.M.; Alvarez, R.D.; Conner, M.G.; Schneider, D.; Chen, D.; Landen, C.N. Using heterogeneity of the patient-derived xenograft model to identify the chemoresistant population in ovarian cancer. Oncotarget 2014, 5, 8750-8764. [CrossRef] [PubMed]

44. Xu, Y.; Silver, D.F.; Yang, N.-P.; Oflazoglu, E.; Hempling, R.E.; Piver, M.; Repasky, E.A. Characterization of Human Ovarian Carcinomas in a SCID Mouse Model. Gynecol. Oncol. 1999, 72, 161-170. [CrossRef] [PubMed]

45. Bankert, R.B.; Balu-Iyer, S.V.; Odunsi, K.; Shultz, L.D.; Kelleher, R.J.; Barnas, J.L.; Simpson-Abelson, M.; Parsons, R.; Yokota, S.J. Humanized Mouse Model of Ovarian Cancer Recapitulates Patient Solid Tumor Progression, Ascites Formation, and Metastasis. PLoS ONE 2011, 6, e24420. [CrossRef] [PubMed]

46. Liu, J.F.; Palakurthi, S.; Zeng, Q.; Zhou, S.; Ivanova, E.; Huang, W.; Zervantonakis, I.K.; Selfors, L.M.; Shen, Y.; Pritchard, C.C.; et al. Establishment of Patient-Derived Tumor Xenograft Models of Epithelial Ovarian Cancer for Preclinical Evaluation of Novel Therapeutics. Clin. Cancer Res. 2017, 23, 1263-1273. [CrossRef] [PubMed]

47. Press, J.Z.; Kenyon, J.A.; Xue, H.; Miller, M.A.; De Luca, A.; Miller, D.M.; Huntsman, D.G.; Gilks, C.B.; McAlpine, J.N.; Wang, Y. Xenografts of primary human gynecological tumors grown under the renal capsule of NOD/SCID mice show genetic stability during serial transplantation and respond to cytotoxic chemotherapy. Gynecol. Oncol. 2008, 110, 256-264. [CrossRef] [PubMed]

48. Cybulska, P.; Stewart, J.M.; Sayad, A.; Virtanen, C.; Shaw, P.A.; Clarke, B.; Stickle, N.; Bernardini, M.Q.; Neel, B.G. A Genomically Characterized Collection of High-Grade Serous Ovarian Cancer Xenografts for Preclinical Testing. Am. J. Pathol. 2018, 188, 1120-1131. [CrossRef]

49. Liu, Y.; Chanana, P.; Davila, J.I.; Hou, X.; Zanfagnin, V.; McGehee, C.D.; Goode, E.L.; Polley, E.C.; Haluska, P.; Weroha, S.J.; et al. Gene expression differences between matched pairs of ovarian cancer patient tumors and patient-derived xenografts. Sci. Rep. 2019, 9, 6314. [CrossRef]

50. Kolfschoten, G.M.; Schlüper, H.M.; Erkelens, C.A.; Pinedo, H.M.; Scheffer, P.G.; Boven, E. Development of a Panel of 15 Human Ovarian Cancer Xenografts for Drug Screening and Determination of the Role of the Glutathione Detoxification System. Gynecol. Oncol. 2000, 76, 362-368. [CrossRef]

51. Vidal, A.; Muñoz, C.; Guillén, M.-J.; Moretó, J.; Puertas, S.; Martínez-Iniesta, M.; Figueras, A.; Padullés, L.; García-Rodriguez, F.J.; Berdiel-Acer, M.; et al. Lurbinectedin (PM01183), a New DNA Minor Groove Binder, Inhibits Growth of Orthotopic Primary Graft of Cisplatin-Resistant Epithelial Ovarian Cancer. Clin. Cancer Res. 2012, 18, 5399-5411. [CrossRef] [PubMed]

52. Ricci, F.; Bizzaro, F.; Cesca, M.; Guffanti, F.; Ganzinelli, M.; Decio, A.; Ghilardi, C.; Perego, P.; Fruscio, R.; Buda, A.; et al. Patient-Derived Ovarian Tumor Xenografts Recapitulate Human Clinicopathology and Genetic Alterations. Cancer Res. 2014, 74, 6980-6990. [CrossRef] [PubMed]

53. Topp, M.D.; Hartley, L.; Cook, M.; Heong, V.; Boehm, E.; McShane, L.; Pyman, J.; McNally, O.; Ananda, S.; Harrell, M.; et al. Molecular correlates of platinum response in human high-grade serous ovarian cancer patient-derived xenografts. Mol. Oncol. 2014, 8, 656-668. [CrossRef] 
54. Groeneweg, J.W.; DiGloria, C.M.; Yuan, J.; Richardson, W.S.; Growdon, W.B.; Sathyanarayanan, S.; Foster, R.; Rueda, B.R. Inhibition of Notch Signaling in Combination with Paclitaxel Reduces Platinum-Resistant Ovarian Tumor Growth. Front. Oncol. 2014, 4, 171. [CrossRef] [PubMed]

55. Scott, C.L.; Becker, M.A.; Haluska, P.; Samimi, G. Patient-Derived Xenograft Models to Improve Targeted Therapy in Epithelial Ovarian Cancer Treatment. Front. Oncol. 2013, 3, 295. [CrossRef]

56. Kortmann, U.; McAlpine, J.N.; Xue, H.; Guan, J.; Ha, G.; Tully, S.; Shafait, S.; Lau, A.; Cranston, A.N.; O'Connor, M.J.; et al. Tumor growth inhibition by olaparib in BRCA2 germline-mutated patient-derived ovarian cancer tissue xenografts. Clin. Cancer Res. 2011, 17, 783-791. [CrossRef]

57. George, E.; Kim, H.; Krepler, C.; Wenz, B.; Makvandi, M.; Tanyi, J.L.; Brown, E.; Zhang, R.; Brafford, P.; Jean, S.; et al. A patient-derived-xenograft platform to study BRCA-deficient ovarian cancers. JCI Insight 2017, 2. [CrossRef] [PubMed]

58. Bhattacharya, R.; Kwon, J.; Ali, B.; Wang, E.; Patra, S.; Shridhar, V.; Mukherjee, P. Role of Hedgehog Signaling in Ovarian Cancer. Clin. Cancer Res. 2008, 14, 7659-7666. [CrossRef]

59. McCann, C.K.; Growdon, W.B.; Kulkarni-Datar, K.; Curley, M.D.; Friel, A.M.; Proctor, J.L.; Sheikh, H.; Deyneko, I.; Ferguson, J.A.; Vathipadiekal, V.; et al. Inhibition of Hedgehog Signaling Antagonizes Serous Ovarian Cancer Growth in a Primary Xenograft Model. PLoS ONE 2011, 6, e28077. [CrossRef] [PubMed]

60. Harris, F.R.; Zhang, P.; Yang, L.; Hou, X.; Leventakos, K.; Weroha, S.J.; Vasmatzis, G.; Kovtun, I.V. Targeting HER2 in patient-derived xenograft ovarian cancer models sensitizes tumors to chemotherapy. Mol. Oncol. 2019, 13, 132-152. [CrossRef] [PubMed]

61. Eoh, K.J.; Chung, Y.S.; Lee, S.H.; Park, S.A.; Kim, H.J.; Yang, W.; Lee, I.O.; Lee, J.Y.; Cho, H.; Chay, D.B.; et al. Comparison of Clinical Features and Outcomes in Epithelial Ovarian Cancer according to Tumorigenicity in Patient-Derived Xenograft Models. Cancer Res. Treat 2018, 50, 956-963. [CrossRef]

62. Dong, R.; Qiang, W.; Guo, H.; Xu, X.; Kim, J.J.; Mazar, A.; Kong, B.; Wei, J.-J. Histologic and molecular analysis of patient derived xenografts of high-grade serous ovarian carcinoma. J. Hematol. Oncol. 2016, 9 , 1376. [CrossRef] [PubMed]

63. McCallum, H.M.; Lowther, G.W. Long-term culture of primary breast cancer in defined medium. Breast Cancer Res. Treat. 1996, 39, 247-259. [CrossRef] [PubMed]

64. Gazdar, A.F.; Kurvari, V.; Virmani, A.; Gollahon, L.; Sakaguchi, M.; Westerfield, M.; Kodagoda, D.; Stasny, V.; Cunningham, H.T.; Wistuba, I.I.; et al. Characterization of paired tumor and non-tumor cell lines established from patients with breast cancer. Int. J. Cancer 1998, 78, 766-774. [CrossRef]

65. Zaniolo, K.; Bergeron, M.-A.; Weidmann, C.; Fournier, F.; Droit, A.; Morcos, M.W.; Landreville, S.; Guérin, S.L.; Mouriaux, F.; De La Fouchardière, A. Effects of Long-term Serial Passaging on the Characteristics and Properties of Cell Lines Derived From Uveal Melanoma Primary Tumors. Invest. Opthalmol. Vis. Sci. 2016, $57,5288$.

66. Ince, T.A.; Sousa, A.D.; Jones, M.A.; Harrell, J.C.; Agoston, E.S.; Krohn, M.; Selfors, L.M.; Liu, W.; Chen, K.; Yong, M.; et al. Characterization of twenty-five ovarian tumour cell lines that phenocopy primary tumours. Nat. Commun. 2015, 6, 7419. [CrossRef]

67. Weiswald, L.-B.; Bellet, D.; Dangles-Marie, V. Spherical Cancer Models in Tumor Biology. Neoplasia 2015, 17, 1-15. [CrossRef] [PubMed]

68. Ricci-Vitiani, L.; Lombardi, D.G.; Pilozzi, E.; Biffoni, M.; Todaro, M.; Peschle, C.; De Maria, R. Identification and expansion of human colon-cancer-initiating cells. Nature 2007, 445, 111-115. [CrossRef]

69. Ponti, D. Isolation and In vitro Propagation of Tumorigenic Breast Cancer Cells with Stem/Progenitor Cell Properties. Cancer Res. 2005, 65, 5506-5511. [CrossRef]

70. Zhang, Y.; Xu, W.; Guo, H.; Zhang, Y.; He, Y.; Lee, S.H.; Song, X.; Li, X.; Guo, Y.; Zhao, Y.; et al. NOTCH1 Signaling Regulates Self-Renewal and Platinum Chemoresistance of Cancer Stem-like Cells in Human Non-Small Cell Lung Cancer. Cancer Res. 2017, 77, 3082-3091. [CrossRef]

71. A Bapat, S.; Mali, A.M.; Koppikar, C.B.; Kurrey, N.K. Stem and progenitor-like cells contribute to the aggressive behavior of human epithelial ovarian cancer. Cancer Res. 2005, 65, 3025-3029. [CrossRef]

72. Zhang, S.; Balch, C.; Chan, M.W.; Lai, H.-C.; Matei, D.; Schilder, J.M.; Yan, P.S.; Huang, T.H.-M.; Nephew, K.P. Identification and Characterization of Ovarian Cancer-Initiating Cells from Primary Human Tumors. Cancer Res. 2008, 68, 4311-4320. [CrossRef] 
73. Ishiguro, T.; Sato, A.; Ohata, H.; Ikarashi, Y.; Takahashi, R.U.; Ochiya, T.; Yoshida, M.; Tsuda, H.; Onda, T.; Kato, T.; et al. Establishment and Characterization of an In Vitro Model of Ovarian Cancer Stem-like Cells with an Enhanced Proliferative Capacity. Cancer Res. 2016, 76, 150-160. [CrossRef]

74. Raghavan, S.; Mehta, P.; Ward, M.R.; Bregenzer, M.E.; Fleck, E.M.A.; Tan, L.; McLean, K.; Buckanovich, R.J.; Mehta, G. Personalized Medicine Based Approach to Model Patterns of Chemoresistance, and Tumor Recurrence Using Ovarian Cancer Stem Cell Spheroids. Clin. Cancer Res. 2017, 23, 6934-6945. [CrossRef] [PubMed]

75. Kondo, J.; Endo, H.; Okuyama, H.; Ishikawa, O.; Iishi, H.; Tsujii, M.; Ohue, M.; Inoue, M. Retaining cell-cell contact enables preparation and culture of spheroids composed of pure primary cancer cells from colorectal cancer. PNAS 2011, 108, 6235-6240. [CrossRef]

76. Kiyohara, Y.; Yoshino, K.; Kubota, S.; Okuyama, H.; Endo, H.; Ueda, Y.; Kimura, T.; Kimura, T.; Kamiura, S.; Inoue, M. Drug screening and grouping by sensitivity with a panel of primary cultured cancer spheroids derived from endometrial cancer. Cancer Sci. 2016, 107, 452-460. [CrossRef] [PubMed]

77. Endo, H.; Okami, J.; Okuyama, H.; Kumagai, T.; Uchida, J.; Kondo, J.; Takehara, T.; Nishizawa, Y.; Imamura, F.; Higashiyama, M.; et al. Spheroid Culture of Primary Lung Cancer Cells with Neuregulin 1/HER3 Pathway Activation. J. Thorac. Oncol. 2013, 8, 131-139. [CrossRef] [PubMed]

78. Kondo, J.; Ekawa, T.; Endo, H.; Yamazaki, K.; Tanaka, N.; Kukita, Y.; Okuyama, H.; Okami, J.; Imamura, F.; Ohue, M.; et al. High-throughput screening in colorectal cancer tissue-originated spheroids. Cancer Sci. 2019, 110, 345-355. [CrossRef] [PubMed]

79. Tamura, H.; Higa, A.; Hoshi, H.; Hiyama, G.; Takahashi, N.; Ryufuku, M.; Morisawa, G.; Yanagisawa, Y.; Ito, E.; Imai, J.-I.; et al. Evaluation of anticancer agents using patient-derived tumor organoids characteristically similar to source tissues. Oncol. Rep. 2018, 40, 635-646. [CrossRef]

80. Sato, T.; Vries, R.G.; Snippert, H.J.; Van De Wetering, M.; Barker, N.; Stange, D.E.; Van Es, J.H.; Abo, A.; Kujala, P.; Peters, P.J.; et al. Single Lgr5 stem cells build crypt-villus structures in vitro without a mesenchymal niche. Nature 2009, 459, 262-265. [CrossRef] [PubMed]

81. Boretto, M.; Cox, B.; Noben, M.; Hendriks, N.; Fassbender, A.; Roose, H.; Amant, F.; Timmerman, D.; Tomassetti, C.; Vanhie, A.; et al. Development of organoids from mouse and human endometrium showing endometrial epithelium physiology and long-term expandability. Development 2017, 144, 1775-1786. [CrossRef]

82. Kessler, M.; Hoffmann, K.; Brinkmann, V.; Thieck, O.; Jackisch, S.; Toelle, B.; Berger, H.; Mollenkopf, H.-J.; Mangler, M.; Sehouli, J.; et al. The Notch and Wnt pathways regulate stemness and differentiation in human fallopian tube organoids. Nat. Commun. 2015, 6, 8989. [CrossRef] [PubMed]

83. DeWard, A.D.; Cramer, J.; Lagasse, E. Cellular heterogeneity in the mouse esophagus implicates the presence of a non-quiescent epithelial stem cell population. Cell Rep. 2014, 9, 701-711. [CrossRef]

84. Bartfeld, S.; Bayram, T.; van de Wetering, M.; Huch, M.; Begthel, H.; Kujala, P.; Vries, R.; Peters, P.J.; Clevers, $\mathrm{H}$. In vitro expansion of human gastric epithelial stem cells and their responses to bacterial infection. Gastroenterology 2015, 148, 126-136. [CrossRef] [PubMed]

85. Chen, Y.-W.; Huang, S.X.; De Carvalho, A.L.R.T.; Ho, S.-H.; Islam, M.N.; Volpi, S.; Notarangelo, L.D.; Ciancanelli, M.; Casanova, J.-L.; Bhattacharya, J.; et al. A three-dimensional model of human lung development and disease from pluripotent stem cells. Nat. Cell. Biol. 2017, 19, 542-549. [CrossRef]

86. Schumacher, M.A.; Aihara, E.; Feng, R.; Engevik, A.; Shroyer, N.F.; Ottemann, K.M.; Worrell, R.T.; Montrose, M.H.; Shivdasani, R.A.; Zavros, Y. The use of murine-derived fundic organoids in studies of gastric physiology. J. Physiol. 2015, 593, 1809-1827. [CrossRef]

87. Maru, Y.; Orihashi, K.; Hippo, Y. Lentivirus-Based Stable Gene Delivery into Intestinal Organoids. Methods Mol. Biol. 2016, 1422, 13-21.

88. Onuma, K.; Ochiai, M.; Orihashi, K.; Takahashi, M.; Imai, T.; Nakagama, H.; Hippo, Y. Genetic reconstitution of tumorigenesis in primary intestinal cells. PNAS 2013, 110, 11127-11132. [CrossRef]

89. Ochiai, M.; Yoshihara, Y.; Maru, Y.; Matsuura, T.; Izumiya, M.; Imai, T.; Hippo, Y. Kras-driven heterotopic tumor development from hepatobiliary organoids. Carcinogenesis 2019. [CrossRef] [PubMed]

90. Sato, T.; Morita, M.; Tanaka, R.; Inoue, Y.; Nomura, M.; Sakamoto, Y.; Miura, K.; Ito, S.; Sato, I.; Tanaka, N.; et al. Ex vivo model of non-small cell lung cancer using mouse lung epithelial cells. Oncol. Lett. 2017, 14, 6863-6868. [CrossRef] 
91. Drost, J.; Van Jaarsveld, R.H.; Ponsioen, B.; Zimberlin, C.; Van Boxtel, R.; Buijs, A.; Sachs, N.; Overmeer, R.M.; Offerhaus, G.J.; Begthel, H.; et al. Sequential cancer mutations in cultured human intestinal stem cells. Nature 2015, 521, 43-47. [CrossRef] [PubMed]

92. O’Rourke, K.P.; Loizou, E.; Livshits, G.; Schatoff, E.M.; Baslan, T.; Manchado, E.; Simon, J.; Romesser, P.B.; Leach, B.; Han, T.; et al. Transplantation of engineered organoids enables rapid generation of metastatic mouse models of colorectal cancer. Nat. Biotechnol. 2017, 35, 577-582. [CrossRef]

93. Zhao, H.; Yan, C.; Hu, Y.; Mu, L.; Huang, K.; Li, Q.; Li, X.; Tao, D.; Qin, J. Sphere-forming assay vs. organoid culture: Determining long-term stemness and the chemoresistant capacity of primary colorectal cancer cells. Int. J. Oncol. 2019, 54, 893-904. [CrossRef]

94. Sato, T.; Stange, D.E.; Ferrante, M.; Vries, R.G.; Van Es, J.H.; Brink, S.V.D.; Van Houdt, W.J.; Pronk, A.; Van Gorp, J.; Siersema, P.D.; et al. Long-term Expansion of Epithelial Organoids From Human Colon, Adenoma, Adenocarcinoma, and Barrett's Epithelium. Gastroenterology 2011, 141, 1762-1772. [CrossRef] [PubMed]

95. Boj, S.F.; Hwang, C.I.; Baker, L.A.; Chio, I.I.C.; Engle, D.D.; Corbo, V.; Jager, M.; Ponz-Sarvise, M.; Tiriac, H.; Spector, M.S.; et al. Organoid models of human and mouse ductal pancreatic cancer. Cell 2015, 160, 324-338. [CrossRef] [PubMed]

96. Yan, H.H.; Siu, H.C.; Law, S.; Ho, S.L.; Yue, S.S.; Tsui, W.Y.; Chan, D.; Chan, A.S.; Ma, S.; Lam, K.O.; et al. A Comprehensive Human Gastric Cancer Organoid Biobank Captures Tumor Subtype Heterogeneity and Enables Therapeutic Screening. Cell Stem Cell 2018, 23, 882-897.e11. [CrossRef] [PubMed]

97. Gao, D.; Vela, I.; Sboner, A.; Iaquinta, P.J.; Karthaus, W.R.; Gopalan, A.; Dowling, C.; Wanjala, J.N.; Undvall, E.A.; Arora, V.K.; et al. Organoid cultures derived from patients with advanced prostate cancer. Cell 2014, 159, 176-187. [CrossRef]

98. Sachs, N.; De Ligt, J.; Kopper, O.; Gogola, E.; Bounova, G.; Weeber, F.; Balgobind, A.V.; Wind, K.; Gracanin, A.; Begthel, H.; et al. A Living Biobank of Breast Cancer Organoids Captures Disease Heterogeneity. Cell 2018, 172, 373-386.e10. [CrossRef]

99. Li, X.; Francies, H.E.; Secrier, M.; Perner, J.; Miremadi, A.; Galeano-Dalmau, N.; Barendt, W.J.; Letchford, L.; Leyden, G.M.; Goffin, E.K.; et al. Organoid cultures recapitulate esophageal adenocarcinoma heterogeneity providing a model for clonality studies and precision therapeutics. Nat. Commun. 2018, 9, 2983. [CrossRef] [PubMed]

100. Lee, S.H.; Hu, W.; Matulay, J.T.; Silva, M.V.; Owczarek, T.B.; Kim, K.; Chua, C.W.; Barlow, L.J.; Kandoth, C.; Williams, A.B.; et al. Tumor Evolution and Drug Response in Patient-Derived Organoid Models of Bladder Cancer. Cell 2018, 173, 515-528.e17. [CrossRef]

101. Girda, E.; Huang, E.C.; Leiserowitz, G.S.; Smith, L.H. The Use of Endometrial Cancer Patient-Derived Organoid Culture for Drug Sensitivity Testing Is Feasible. Int. J. Gynecol. Cancer. 2017, 27, 1701-1707. [CrossRef] [PubMed]

102. Pauli, C.; Hopkins, B.D.; Prandi, D.; Shaw, R.; Fedrizzi, T.; Sboner, A.; Sailer, V.; Augello, M.; Puca, L.; Rosati, R.; et al. Personalized In Vitro and In Vivo Cancer Models to Guide Precision Medicine. Cancer Discov. 2017, 7, 462-477. [CrossRef] [PubMed]

103. Vlachogiannis, G.; Hedayat, S.; Vatsiou, A.; Jamin, Y.; Fernández-Mateos, J.; Khan, K.; Lampis, A.; Eason, K.; Huntingford, I.; Burke, R.; et al. Patient-derived organoids model treatment response of metastatic gastrointestinal cancers. Science 2018, 359, 920-926. [CrossRef] [PubMed]

104. Van De Wetering, M.; Francies, H.E.; Francis, J.M.; Bounova, G.; Iorio, F.; Pronk, A.; Van Houdt, W.; Van Gorp, J.; Taylor-Weiner, A.; Kester, L.; et al. Prospective derivation of a Living Organoid Biobank of colorectal cancer patients. Cell 2015, 161, 933-945. [CrossRef]

105. Roerink, S.F.; Sasaki, N.; Lee-Six, H.; Young, M.D.; Alexandrov, L.B.; Behjati, S.; Mitchell, T.J.; Grossmann, S.; Lightfoot, H.; Egan, D.A.; et al. Intra-tumour diversification in colorectal cancer at the single-cell level. Nature 2018, 556, 457-462. [CrossRef]

106. Öhlund, D.; Handly-Santana, A.; Biffi, G.; Elyada, E.; Almeida, A.S.; Ponz-Sarvise, M.; Corbo, V.; Oni, T.E.; Hearn, S.A.; Lee, E.J.; et al. Distinct populations of inflammatory fibroblasts and myofibroblasts in pancreatic cancer. J. Exp. Med. 2017, 214, 579-596. [CrossRef] [PubMed]

107. Dijkstra, K.K.; Cattaneo, C.M.; Weeber, F.; Chalabi, M.; Van De Haar, J.; Fanchi, L.F.; Slagter, M.; Van Der Velden, D.L.; Kaing, S.; Kelderman, S.; et al. Generation of Tumor-Reactive T Cells by Co-culture of Peripheral Blood Lymphocytes and Tumor Organoids. Cell 2018, 174, 1586-1598.e12. [CrossRef] [PubMed] 
108. Miyoshi, H.; Ajima, R.; Luo, C.T.-Y.; Yamaguchi, T.P.; Stappenbeck, T.S. Wnt5a Potentiates TGF- $\beta$ Signaling to Promote Colonic Crypt Regeneration after Tissue Injury. Science 2012, 338, 108-113. [CrossRef]

109. Miyoshi, H.; Stappenbeck, T.S. In vitro expansion and genetic modification of gastrointestinal stem cells in spheroid culture. Nat. Protoc. 2013, 8, 2471-2482. [CrossRef]

110. Tiriac, H.; Bucobo, J.C.; Tzimas, D.; Grewel, S.; LaComb, J.F.; Rowehl, L.M.; Nagula, S.; Wu, M.; Kim, J.; Sasson, A.; et al. Successful creation of pancreatic cancer organoids by means of EUS-guided fine-needle biopsy sampling for personalized cancer treatment. Gastrointest. Endosc. 2018, 87, 1474-1480. [CrossRef]

111. Jabs, J.; Zickgraf, F.M.; Park, J.; Wagner, S.; Jiang, X.; Jechow, K.; Kleinheinz, K.; Toprak, U.H.; A Schneider, M.; Meister, M.; et al. Screening drug effects in patient-derived cancer cells links organoid responses to genome alterations. Mol. Syst. Biol. 2017, 13, 955. [CrossRef]

112. Hill, S.J.; Decker, B.; Roberts, E.A.; Horowitz, N.S.; Muto, M.G.; Worley, M.J.; Feltmate, C.M.; Nucci, M.R.; Swisher, E.M.; Nguyen, H.; et al. Prediction of DNA Repair Inhibitor Response in Short-Term Patient-Derived Ovarian Cancer Organoids. Cancer Discov. 2018, 8, 1404-1421. [CrossRef]

113. Kopper, O.; De Witte, C.J.; Lõhmussaar, K.; Valle-Inclan, J.E.; Hami, N.; Kester, L.; Balgobind, A.V.; Korving, J.; Proost, N.; Begthel, H.; et al. An organoid platform for ovarian cancer captures intra- and interpatient heterogeneity. Nat. Med. 2019, 25, 838-849. [CrossRef] [PubMed]

114. Maru, Y.; Tanaka, N.; Itami, M.; Hippo, Y. Efficient use of patient-derived organoids as a preclinical model for gynecologic tumors. Gynecol. Oncol. 2019. [CrossRef] [PubMed]

115. Maru, Y.; Onuma, K.; Ochiai, M.; Imai, T.; Hippo, Y. Shortcuts to intestinal carcinogenesis by genetic engineering in organoids. Cancer Sci. 2019, 110, 858-866. [CrossRef] [PubMed]

116. Kenny, H.A.; Krausz, T.; Yamada, S.D.; Lengyel, E. Use of a novel 3D culture model to elucidate the role of mesothelial cells, fibroblasts and extra-cellular matrices on adhesion and invasion of ovarian cancer cells to the omentum. Int. J. Cancer 2007, 121, 1463-1472. [CrossRef] [PubMed]

117. Li, S.-S.; Ip, C.K.M.; Tang, M.Y.H.; Sy, S.K.H.; Yung, S.; Chan, T.-M.; Yang, M.; Shum, H.C.; Wong, A.S. Modeling Ovarian Cancer Multicellular Spheroid Behavior in a Dynamic 3D Peritoneal Microdevice. J. Vis. Exp. 2017. [CrossRef]

(C) 2019 by the authors. Licensee MDPI, Basel, Switzerland. This article is an open access article distributed under the terms and conditions of the Creative Commons Attribution (CC BY) license (http://creativecommons.org/licenses/by/4.0/). 